\title{
A global survey of urban water tariffs: are they sustainable, efficient and fair?
}

\author{
David Zetland $^{\mathrm{a} *}$ and Christopher Gasson ${ }^{\mathrm{b}}$ \\ ${ }^{a}$ Wageningen University, Environmental and Natural Resource Economics, Wageningen, \\ the Netherlands; ${ }^{b}$ Global Water Intelligence, The Jam Factory, Oxford, UK
}

(Received 15 December 2011; accepted 1 May 2012)

\begin{abstract}
This paper examines the relations between tariffs and sustainability, efficiency and equity, using a unique data-set for 308 cities in 102 countries. Higher water tariffs are correlated with lower per capita consumption, smaller local populations, lower water availability, higher demand and a lower risk of shortage. Aggregating to the national level, higher tariffs are correlated with higher GDP and better governance. A different country-level analysis shows that a higher percentage of the population with water service is correlated with better governance, higher GDP and a greater risk of water shortage. The relation between water prices and service coverage is statistically inconsistent.
\end{abstract}

Keywords: water tariff; access to water; shortage; governance; subsidies; less developed countries

\section{Introduction}

Residential water and wastewater tariffs are generally linked to the cost of building, operating and maintaining drinking-water and wastewater systems, but tariffs rarely recover the full cost of service. Economists define the 'full cost of service' as the cost of operations, capital replacement, system expansion and - most important - the opportunity cost of using urban water today instead of saving it for tomorrow or using it elsewhere, e.g. for the environment or irrigation. Policies that reduce the price of water below the full cost of service are likely to increase unsustainable water consumption, causing stress on supplies; dependence on outside sources of financing and the political interference that comes with it; service interruptions due to underfunding of operating and capital costs; and inequality due to limits on service to outlying, informal and newly settled areas.

These outcomes result when water managers with limited water, capital budgets and operating resources must choose whom to serve among multiple demands. The most common choice - to serve the powerful and rich over the weak and poor - is particularly acute in developing countries struggling to extend clean water service to the entire population (Segerfeldt, 2005; North, Wallis, \& Weingast, 2009). The United Nations Development Programme (UNDP, 2006, pp. 2-3), for example, writes:

In many countries scarcity is the product of public policies that have encouraged overuse of water through subsidies and underpricing. There is more than enough water in the world for domestic purposes, for agriculture and for industry. The problem is that some people notably the poor - are systematically excluded from access by their poverty, by their limited legal rights or by public policies that limit access to the infrastructures that provide water for

\footnotetext{
*Corresponding author. Email: dzetland@gmail.com
} 
Table 1. Descriptive statistics for 2011 GWI data.

\begin{tabular}{llcccll}
\hline Variable & Units & Observations & Mean & Std. Dev. & Min & Max \\
\hline Water & USD per m $^{3}$ & 308 & 1.21 & 1.13 & 0 & 7.54 \\
Wastewater & USD per m $^{3}$ & 248 & 1.02 & 1.07 & 0 & 5.68 \\
Combined & USD per m & 308 & 2.02 & 1.90 & 0 & 10.00 \\
GDP & USD per capita & 308 & 22,630 & 20,600 & 345 & 108,230 \\
Water tariff change & percent from 2010 & 272 & 1.90 & 18.20 & -76 & 136 \\
Wastewater tariff change & percent from 2010 & 213 & 4.16 & 23.86 & -57 & 279 \\
\hline
\end{tabular}

Source: GWI (2011a).

life and for livelihoods. In short, scarcity is manufactured through political processes and institutions that disadvantage the poor.

This sentiment should be borne in mind when examining the variables describing the relations among water tariffs and measures of sustainability, efficiency and equity.

\section{Data}

The primary data come from Global Water Intelligence's 2011 survey of water and wastewater tariffs for 308 cities in 102 countries (GWI, 2011a). These cities were chosen for their large populations and representative natures. GWI gathered data on tariffs and GDP per capita via phone, email and internet; converted local currencies into 2011 USD equivalents using current market exchange rates; and normalized the price of receiving one cubic metre of drinking-water or wastewater service by adding the charge for consuming $15 \mathrm{~m}^{3}$ to the monthly fixed charge and then dividing the result by 15 . This last step makes it possible to compare water prices on a standard measure, a necessary step when the cost of service in various locations depends on a mix of fixed and variable charges. Note that GWI's data do not reflect the cost of 'irregular service' to households without connections or capture the range of prices and operating practices within countries; for these, see Rygaard, Binning, and Albrechtsen (2011) and IB-NET (http://www.ib-net.org), respectively. Table 1 gives descriptive statistics for GWI (2011a).

It should be noted that $15 \mathrm{~m}^{3}$ per year works out to about 40 litres per day, a number that most households will exceed. The World Health Organization defines 20 litres per capita per day (LCD) to be a minimum humanitarian standard (Howard \& Bartram, 2003); Chenoweth (2008) calculates that 135 LCD is a minimum consistent with economic and social development. The presence of fixed charges means that GWI's cost per cubic metre at a consumption rate of 40 litres per day may overstate the average cost per cubic metre for a household that consumes 200 litres per day - or it may not: increasing block rates may make the average cost per cubic metre at higher consumption volumes significantly higher.

\section{Some notes on water and wastewater tariffs}

Most water utilities operate under some form of political or regulatory price control that aims at minimizing tariffs, subject to covering some or all operating and capital costs, which vary with local labour rates, the age and condition of infrastructure, the rate of infrastructure maintenance and replacement, policies on water pricing and subsidies, and water scarcity. Labour costs generally rise with GDP, but they are also affected by over- or under-staffing, public vs. private operation, union or civil-servant status, and so on. Infrastructure conditions vary with system age and extent, service mandates, management changes in the past or 
anticipated future, and the ebb and flow of financing. Policies that subsidize water prices, shift costs among user groups or fail to reduce theft lead to dependence on outside funding, increased debt, or reductions in maintenance. Water scarcity can affect prices by forcing a utility to spend more money on expensive sources (e.g. desalination or wastewater recovery) or by reducing the volume of water available to customers, which means that the price per unit of water sold has to rise so that total revenues cover (mostly fixed) total costs. It is very difficult to know whether or how these institutional factors affect water and wastewater prices over time, but their variety suggests that policies create a range of effects (Hanemann, 2005; Whittington, Hanemann, Sadoff, \& Jeuland, 2009).

The high cost of Belgian capital and labour thus explains why water in Gent costs $\$ 7.54 / \mathrm{m}^{3}$ (all prices in 2011 US dollars) in the same way that cheap labour and capital might explain Cairo's cost of $\$ 0.04 / \mathrm{m}^{3}$, but these prices are not directly proportional to income or local costs. Belgian GDP per capita is 14 times Egypt's, but Gent's water tariff is 188 times Cairo's. Political factors can even invert prices: Ireland and Saudi Arabia are wealthier countries than Egypt, but water is free in Dublin and only $\$ 0.03 / \mathrm{m}^{3}$ in Jeddah. The big difference between minimum and maximum prices does not mean that most prices are roughly in the middle - the median price per cubic metre of water is $\$ 0.92$. Water tariffs also vary within countries. In the countries with the most cities in the survey (USA with 27, China with 25 and India with 17) the minimum/median/maximum prices per cubic metre of water are $\$ 0.53 / 1.13 / 3.14$ in the US, $\$ 0.17 / 0.35 / 0.59$ in China, and $\$ 0.05 / 0.11 / 0.28$ in India. There may be many reasons for prices that vary by a factor of four or more, but the lesson is clear: no country has 'average' water prices.

Wastewater charges are more complicated. Most people are willing to pay for drinking water service to their houses, but wastewater systems handle rainwater flows as well as municipal and industrial discharges. Some systems clean the water before it leaves the area, while others merely export raw sewage. These mixed 'services' make it harder to establish or set wastewater charges. Residential water is free in Cork, Dublin, Belfast, and Ashgabat; these cities - and 58 more - also do not charge for wastewater service, so they cover costs with outside funding or water sales ( 8 of the 10 top water tariffs are in cities that do not charge for wastewater), or they underinvest in the wastewater system.

Other policies change the price per unit of water with consumption, to induce water conservation or make water 'affordable' to some needy population. Veolia, for example, calculates water prices in Nice and Toulouse according to household characteristics; many Latin American cities set tariffs based on household income; prices in Israel depend on the source of water and the number of people in the house; and so on. GWI uses the $15 \mathrm{~m}^{3}$ benchmark to make it easier to compare tariff structures in which the price per unit of water may rise with consumption (increasing block rates), fall (decreasing block rates), stay the same (a linear rate), or be zero - as when customers pay a fixed charge per month no matter how much water they use. The most common rate structure in GWI (2011a) is increasing (151 cities), followed by linear (141 cities), decreasing (9 cities) and fixed (7 cities), which includes cities that provide free water. Social equity, likewise, may explain why 'poor' customers or customers who use less water may pay less per unit of water consumed, but social tariffs sometimes benefit rich people intentionally misclassified as 'poor' instead of poor people without connections; sometimes they are not reflected in the price of water but in direct income supports.

It is therefore difficult for outsiders with limited data to know if tariffs are 'fair' or reflect the structure of water costs. Martinez-Espiñeira, García-Valiñas, and GonzálezGómez (2009), Ruester and Zschille (2010), and Thorsten, Eskaf, and Hughes (2009) explore the factors determining water tariffs in great detail. 


\section{GWI's Global Water Risk Index}

This long discussion of the various influences on water tariffs illustrates how the complexity of a structural model of water prices will vary with parameters and variables in each of our 308 cities. Since it is not possible to know all of these structural models affecting water prices (and thus efficiency, sustainability and equity), a reduced-form model was used to understand the major influences on price and consumption data in GWI. The reduced-form model uses factors that indirectly affect prices, i.e., measurements of water availability, demand, and risk of shortage tracked in GWI's proprietary Global Water Risk Index (GWI, 2011c). The GWRI is created by combining over 200 maps, arrays and algorithms containing information about hydrology, population, economic activities, political boundaries and other natural and social factors into spatial and temporal models of supply and demand. The GWRI's $0.5^{\circ} \times 0.5^{\circ}$ resolution groups data into squares that are $55 \mathrm{~km}^{2}$ at the equator and smaller near the poles. These squares are assigned to cities, but they do not match municipal boundaries.

For water availability, the GWRI includes variables for water availability by river basin, storage capacity, historic volumes of rainfall and runoff, frequency of floods and droughts, and so on. Demand data are assembled for the domestic, agricultural and industrial sectors. Demand for domestic water can be met by formal or informal sources. Agricultural water demand is met by precipitation and irrigation. Industrial demand draws data from 13 major industries: power generation, oil and gas, petroleum refining, mining, chemicals, metals, automotive, food and beverages, microelectronics, pulp and paper, textiles, pharmaceuticals and biofuels. The GWRI also reflects the estimated future influences of climate change (Scenario A1B) and sectorial changes on supply and demand (IPCC 2007).

The GWRI's indexed value for risk (i.e., water scarcity) is calculated by simulating supply and demand over a range of potential futures and recording the frequency and magnitudes of instances in which demand exceeds supply. The index takes a value of 1.00 if demand exceeds supply $100 \%$ of the time and 0.00 if demand never exceeds supply. Intermediate values reflect lower frequencies and magnitudes of demand exceeding supply. Current GWRI values for risk tend to be clustered at the extremes: 240 cities face scarcity risk (i.e. 1.00 values) while 108 cities do not ( 0.00 values). These values may correspond to results, since management also matters. Dhaka, Mumbai, Miami and Milwaukee have 0.00 values; Sao Paulo, Paris, New Delhi, Madrid, Atlanta and New York have 1.00 values. Anyone familiar with water management in these cities knows that scarcity risk need not lead to shortage (also see Jenerette \& Larsen [2006] for a complementary analysis of urban water scarcity). Table 2 has descriptive statistics for the GWRI data (all as of 2010).

Table 2. Descriptive statistics for 2010 GWRI data.

\begin{tabular}{llcllll}
\hline Variable & Units & Observations & Mean & Std. Dev. & Min & Max \\
\hline Population & people & 558 & $2,734,000$ & $3,013,000$ & $1,000,000$ & $35,700,000$ \\
Supply & index value & 558 & 1630 & 5320 & -57 & 76,725 \\
Demand & index value & 558 & 160 & 240 & 0 & 2140 \\
Risk & index value & 558 & 0.54 & 0.47 & 0 & 1 \\
\hline
\end{tabular}

Source: GWI (2011c) 


\section{Additional data and caveats}

GWI has tariff data for 308 cities in 102 countries and GWRI data for 588 cities in 112 countries, but these two datasets overlap only for 189 cities in 88 countries. These data are augmented by other data sources such as GWI (2011a) consumption data in litres per capita per day (LCD) for 63 cities; 2008 data on urban access to piped water for 191 countries from WHO/UNICEF (2011); 2009 governance rankings for 213 countries calculated as the average of the World Bank's Governance Indicators for voice and accountability, political stability, government effectiveness, regulatory quality, rule of law and control of corruption (Kaufmann et al., 2010); and 2011 Human Development Index values for 187 countries (UNDP, 2011). Table 3 summarizes these data sources, which overlap with GWI (2011a) data for 102 countries and overlap with both GWI (2011a) and GWI (2011c) for 75 countries.

The authors make several simplifying assumptions to bring tractability to the data. First, it is assumed that tariffs in surveyed cities - a subset of all cities in each country can be combined with national statistics for income and governance and regional statistics for water availability, risk, etc. It is thus assumed, for example, that the populationweighted tariffs of two cities in Bangladesh can be matched against a governance ranking for the whole country. Second, tariffs are examined at a consumption level of $15 \mathrm{~m}^{3}-$ simplifying tariff schedules that may have five or more steps of varying heights (prices per cubic metre) and widths (threshold volumes) into a single price per cubic metre. Third, the discussion of the factors affecting water and wastewater tariffs is simplified by concentrating on water tariffs and assuming that the factors affecting wastewater tariffs are similar. Indeed, water and wastewater tariffs have a $67 \%$ correlation in the 246 cities that charge for both. Correlation is lower when different organizations provide water and wastewater service, when the systems are expanding at different rates, or when tariffs are fixed for one system but based on volume in the other (most volumetric wastewater charges are based on water consumption).

The results, therefore, need to be interpreted with care. Although the regressions explore multivariate relations - an improvement on bivariate analysis - significant variables of interest are often missing (statistics on subsidies from the government or non-revenue water, for example). The multivariate analysis augments the bivariate analysis by clarifying the relative contributions of independent but overlapping variables. More important, correlations are explored among variables that are more likely to have causal relations. Water price and consumption may be correlated, for example, but causality from price to consumption is likely to be stronger. Since panel data are not available, it has been necessary to work with short-term correlations within the crosssectional data. Causality can be assumed where short-run effects are likely to drive the relation in one direction.

Table 3. Descriptive statistics for countries.

\begin{tabular}{llccccc}
\hline Variable & Units & Observations & Mean & Std. Dev. & Min & Max \\
\hline Access to tap water & percent (2008) & 191 & 76 & 29 & 0 & 100 \\
Governance rank & 100 high (2010) & 213 & 50 & 27 & 0 & 98 \\
Human Development Index & 1.0 high & 187 & 0.66 & 0.17 & 0.29 & 0.94 \\
\hline
\end{tabular}

Sources: WHO/UNICEF (2011), Kaufmann et al. (2010) and UNDP (2011). 


\section{Analysis}

Although there are insufficient data on each location in GWI's survey to carry out a detailed structural investigation of the causes and effects of various water tariff regimes, it is possible to carry out a limited analysis to see whether some of the simple relations in the data conform with economic theory. Readers should consider this analysis as the first rather than the last - word on these topics.

\section{Sustainability - balancing demand and supply}

Excess demand is the greatest threat to sustainable water service. Although demand can exceed supply because of natural causes, it is more often the result of poor management. Shortages can be addressed by increasing supply from local or imported sources (at a cost of time, money and environmental impacts) or reducing demand through changes in preferences (forgoing a lawn), adoption of high-efficiency technologies, reductions in system leakages, or price increases that dampen demand. Arbués, García-Valiñas, and Martínez-Espiñeira (2003) and Dalhuisen, Florax, de Groot, and Nijkamp (2003) have made detailed studies of the relation between water prices and demand, but higher prices can also change preferences (Ariely, 2008), incentivize technology adoption, or fund reliability improvements - see Zetland (2011). Higher prices can even benefit the poor, as discussed below.

There must, of course, be a negative relation between price and consumption if higher prices are going to reduce demand. GWI (2011a) data on water prices and average LCD consumption for 63 cities in 34 countries support this relation, as shown in Figure 1. The quality of LCD data - derived by dividing total residential consumption

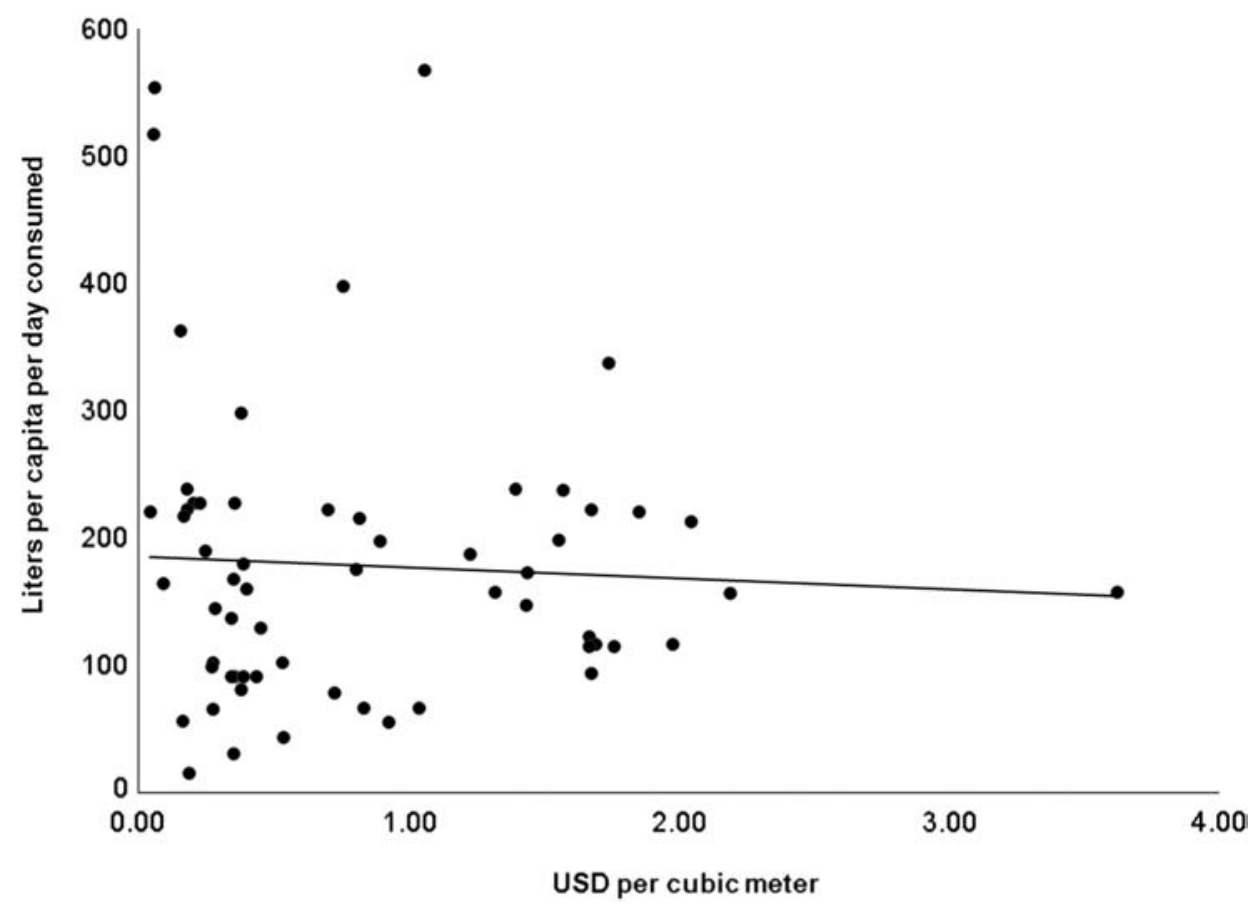

Figure 1. Water tariffs and consumption are negatively correlated. Source: GWI (2011a). 
volume by total population served - varies from very good (exact metering of each residence with a registered number of occupants) to poor (estimated residential consumption in an unmetered system divided by a census statistic for service area population).

Wealth also affects the demand for water, so we ran a simple OLS regression of LCD on water price per cubic metre and GDP per capita. Regression 1 (reported with other regressions in Appendix 1) identifies a negative relation between consumption and price and a positive relation between consumption and wealth. According to estimated coefficients, a $\$ 0.50 / \mathrm{m}^{3}$ price increase from the mean price of $\$ 0.84 / \mathrm{m}^{3}$ is correlated with a 40 LCD drop in consumption from the mean of $180 \mathrm{LCD}$, or a point-estimated price elasticity of -0.37 . This elasticity compares favourably to the median price elasticity of -0.35 that Dalhuisen et al. (2003) report in their survey of 64 studies with 314 elasticities, but remember that GWI's prices are based on assumed consumption, not the actual tariff schedules households face.

\section{Efficiency - investing in reliability}

There are many reasons why water prices can be low (abundant water, low costs, subsidies, government policies, etc.), but they should not be kept low if the resulting high water consumption threatens reliability. Figure 2 affirms this idea, showing that higher tariffs are correlated with a lower risk of shortage, but causality is unclear and numerous 0 or 1 values mean this relation may not be robust.

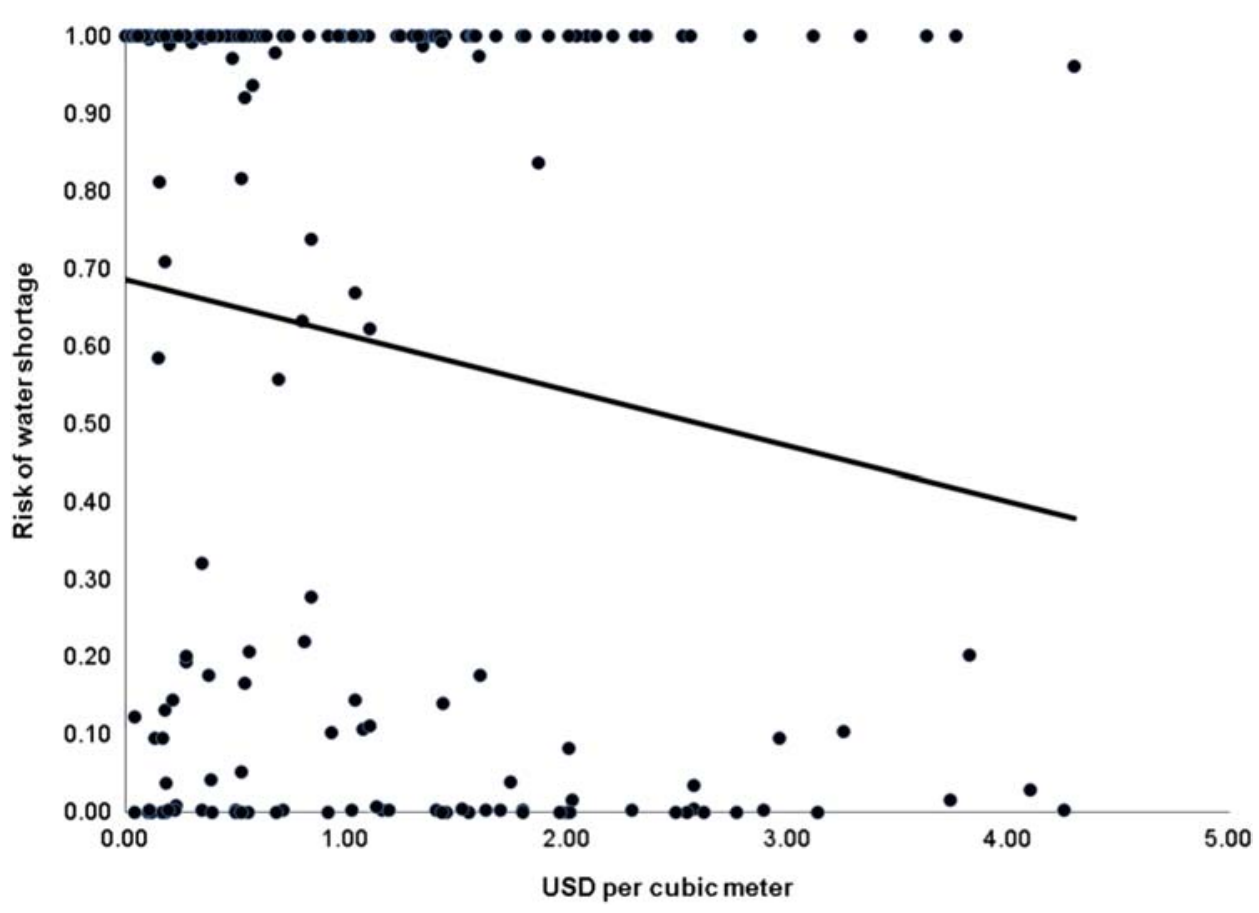

Figure 2. Higher water tariffs are correlated with lower risks of shortage. Source: GWI (2011a, 2011c). 
Water prices need to cover operating costs as well as capital expansion and replacement. According to the UNDP (2006, p. 85):

In many utilities tariffs are set far below the levels needed to meet the overall costs of operation and maintenance. In effect, this delivers a subsidy to all households with private tap connections. On the other side of the balance sheet, the shortfall between revenue and cost will be reflected in transfers from government, rising debt, reduced spending on maintenance or a combination of the three.

Insufficient spending leads to negative present and future impacts, but it is hardly better to fill the gap with debt and/or subsidies that create additional costs. First, they lead managers to spend more time with their financial benefactors and less time managing operations and serving customers. Second, these benefactors can distort strategic or tactical decisions, e.g. where to expand the system or whom to hire. Third, debt and subsidies are inherently volatile: they can and do change much more rapidly than the stream of customer payments. Ireland's financial struggles have led to a plan to reintroduce charges for residential water service - reversing a past populist policy but also creating logistical and financial complications (Taylor, 2010).

The data yield further insights. Regression 2 (water tariff on local population, available water, demand and risk for 189 cities in 75 countries) reveals that higher water tariffs are correlated with a lower population (diseconomies of scale, even though population density may be more relevant), less available water (dearer supplies) and a lower risk of shortage (lower consumption plus funding for reliability). These results do not change if the combined water and wastewater tariff are used or a quadratic term is added for supply that captures the problem of too much water (floods).

If GWI (2011a) city data are aggregated (giving weighs within countries by urban population) and data for service area coverage, governance and GDP per capita are added, this creates a sample of 102 countries.

Figure 3 shows that higher prices and better governance are correlated. This relation holds in Regression 3, which also shows that higher tariffs are correlated with higher GDP and a lower percentage of the urban population receiving water service; see Biswas (2010) for a critical discussion of coverage. Governance results, controlling for income, are consistent with customers paying more when they trust their money will be well spent and with incompetent governments pursuing 'cheap water' populism. Saudi Arabia, for example, has extremely low water prices $\left(\$ 0.03 / \mathrm{m}^{3}\right)$, cheap petrol, and a habit of bribing citizens to reduce civil unrest (The Economist, 2011); it also has a low governance ranking of 44 - tied with Morocco and below Mozambique.

Rearranging these variables in Regression 4 (tap water coverage on governance, tariff, and per capita GDP), confirms the negative relation between coverage and price and the positive correlations between coverage and both governance and GDP. These results are consistent with more money and better governance delivering better water service. The negative correlation of prices - given the lack of coverage variation in developed countries - is consistent with limited but expensive service to urban elites or unsustainable populism in developing countries. Populism often brings poor service: customers in Saudi Arabia, India and other places pay low prices for supplies that are available only a few times per week.

\section{Fairness - serving the poor and everyone else}

Unreliable water service complicates and shortens life for people - as is known from discussions of the Millennium Development Goals, the human right to water, rates of 


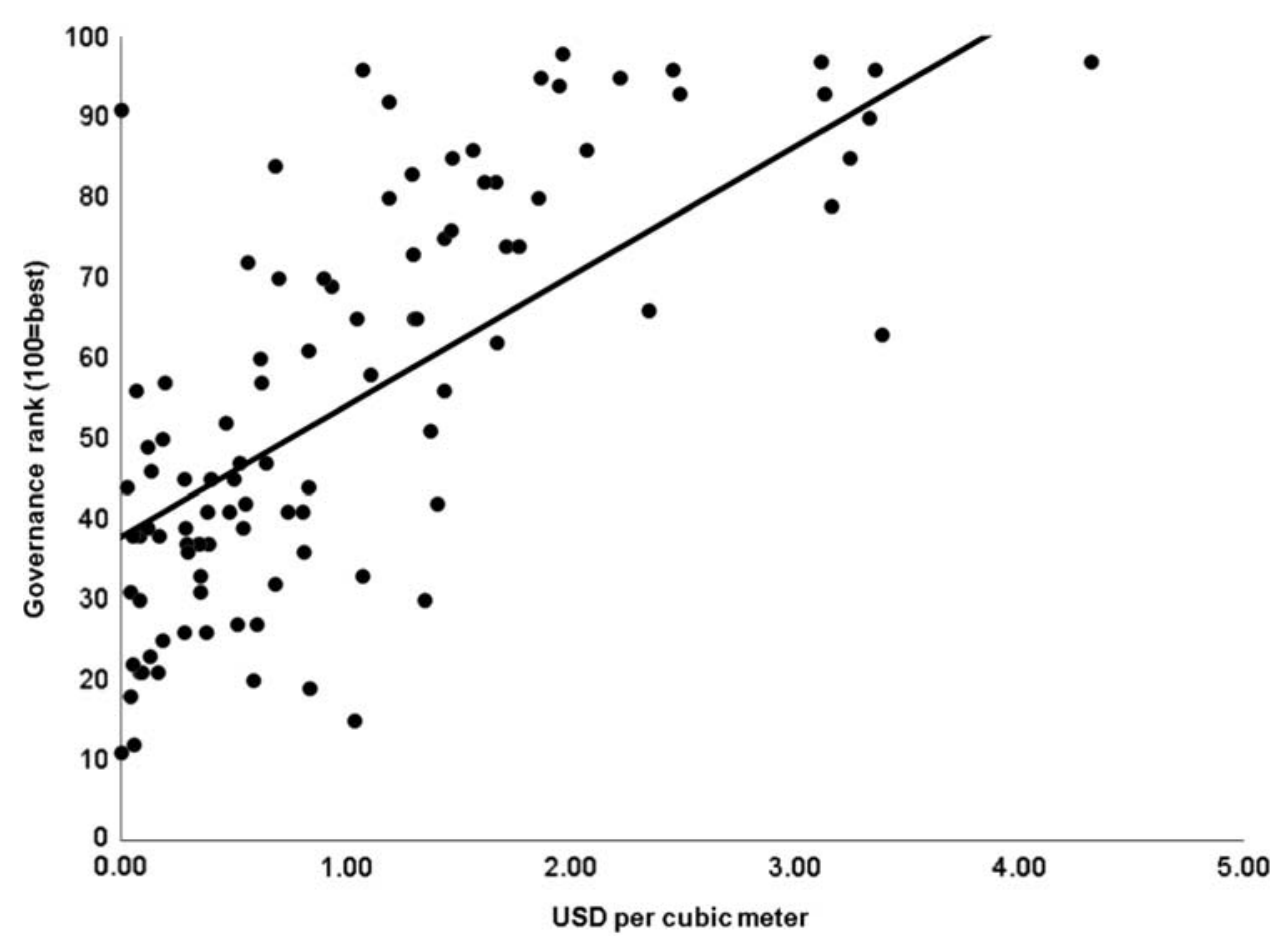

Figure 3. Higher water tariffs are correlated with higher governance ranking. Sources: GWI (2011a) and Kaufmann et al. (2010).

mortality and morbidity, and so on. Although some activists concentrate on lowering the price of water to underserved populations, this goal can backfire (UNDP, 2006, p. 85-86):

Whether utility subsidies are progressive depends on the profile of households connected to the utilities: the lower the proportion of poor households connected, the less progressive the subsidy.... An obvious danger is that excessively high prices will drive users to alternative sources of provision.... Many utilities have been locked in a cycle of underfinancing, undermaintenance and underexpansion. With tariff revenues falling far short of the level needed to maintain the network, there is no money to finance expansion to unserved households on the scale required.

Underserved populations need leverage to get water service from the local water monopoly. They are unlikely to have political power, but financial leverage can work. This phenomenon is observed in the spread of mobile phone service in developing countries, where the number of mobile phone connections per 100 people exceeds the share of people who have piped water to their home, as shown in Figure 4.

Although the poor have their own ways of finding water (see Hammond, Kramer, Tran, Katz, \& Walker, 2007), they are frequently 'protected' by pro-poor policies that create service obligations for low-volume customers without proportional increases in revenues. Cash-strapped utilities respond by withholding service, and the poor pay time and money for lower-quality water (Keener, Luengo, \& Banerjee, 2010; Kjellén \& McGranahan, 2006). It should be noted that GWI's data on social tariffs or programmes are not used to make this point. The negative relationship between normal tariffs and service area in GWI data show that lower prices are correlated with a smaller service area. 


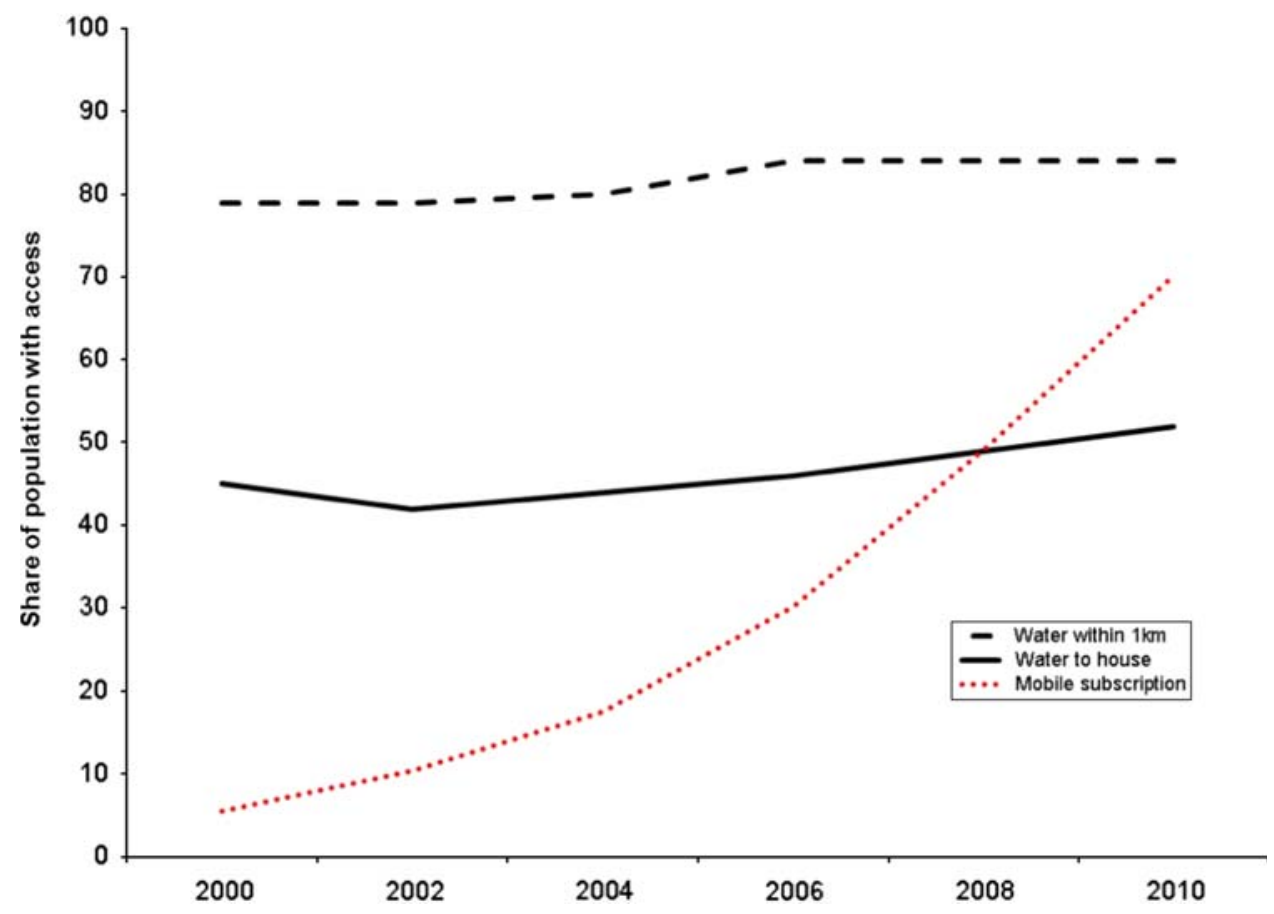

Figure 4. Mobile phones versus water services for rural and urban inhabitants in the developing world. Sources: Mobile phone subscriptions per 100 people from ITU (2011). Access to 'developed' or 'piped' water from annual reports at WHO/UNICEF (2011) for 2000-2008, linearly extrapolated for 2010. (These statistics are not exactly compatible because some people have more than one mobile phone.)

In Regressions 5 and 6, the factors correlated with the provision of piped urban water in 75 countries are explored. Coverage is positively correlated with good governance, risk of local water shortages (perhaps water service is more important with risk) and greater water availability (it is easier to provide service - holding risk constant - when there's more water). It is interesting to see that these regressions do not identify a correlation between water prices and service area, contra Regressions 3 and 4 that used fewer variables. That lack of result may indicate that these data do not provide enough information to clarify the complex relations among the variables.

Regression 7 illustrates this complexity by identifying a significant correlation between aggregated national data for water tariffs (the regressor), governance and GDP (per Regression 3) while failing to establish significance with population served, demand, risk, or water availability - in contrast to their significant, city-level relations in Regression 2. These results suggest that local characteristics - like local water management - may not be clear and consistent when aggregated to a national level.

\section{Discussion}

The results come with two caveats. First, the relations among water prices, sustainability, efficiency and fairness are not standardized around the world. Water prices emerge from a complex interplay of economic, political and social factors that have evolved over time. Second, the data cannot capture the complex relations among quantified and missing 
variables. The next few sections discuss how water prices reflect and affect governance, financial stability and affordability.

\section{Governance}

Good governance at the national level can improve local water management, but it is not a necessary condition. A water utility free of political interference or regulation can independently deliver good or bad service - depending on the principal-agent dynamics between political regulators and water managers whose interactions determine the quality of service customers receive from the water monopoly (Biswas, 2010; Zetland, 2011). It is possible to explore their interactions in a two-by-two grid in which it is clear that diligent regulators and managers deliver good service while lazy regulators and managers deliver bad service. The interesting quadrants are where good managers work in a country with poor governance or lazy managers are overseen by diligent regulators. In the good manager, bad regulator scenario, the manager with an informational advantage can deliver good service despite the regulator. In the bad manager, good regulator scenario, the manager can be replaced and/or forced to serve customers by political regulators with access to basic performance data. This example illustrates how even a partial commitment to good governance can benefit customers.

\section{Full-cost pricing and sustainability}

Although some water utilities are financially self-sufficient, the majority struggle with insufficient revenues. GWI (2011b) estimates that the current global capital spending of $\$ 173$ billion per year falls short of the $\$ 211$ billion per year necessary to maintain capital stock as well as being woefully short of the additional $\$ 360$ billion per year necessary to bring systems up to regulatory standards.

Revenue shortfalls can be addressed in several ways. The most common is to reduce spending on new infrastructure, maintenance, or even operations. The resulting deterioration in service harms existing customers and breaches the public utility promise to provide services to all of the public, some of who turn to expensive but reliable selfsufficient solutions (Rygaard et al., 2011; UNDP, 2006). The second response is to hope for hidden and overt subsidies from politicians that can evaporate with a change of administration or financial crisis. The third response is to outsource the problem to private operators who bring finance and expertise in exchange for the political permission to raise prices, or insource the problem by giving public utilities permission to raise prices.

The findings - that higher tariffs are associated with lower consumption and lower risk of shortage - dovetail nicely with the need to invest more in drinking-water and wastewater infrastructure (UNDP, 2006). These correlations are no proof of impact, but it is hard to argue that higher prices leading to higher spending on services cannot increase reliability. The inconclusive results on the relation between higher prices and service area may be even more important, given that the biggest barrier to higher prices is the fear that they may make water too expensive for the poor.

\section{Affordability}

People concerned about water affordability make two assumptions that weaken their arguments. The first is that higher prices will harm the poor. That idea - simple in theory - does not hold when higher prices are used to extend service to people relying 
previously on informal water providers. GWI (2011b) discusses how citizens of Phnom Phen, Manila, and other poor areas now pay less for full-cost-recovery services that deliver better water than the expensive, unreliable and unhealthy water they purchased previously from informal sellers. The second weakness is revealed by comparing water prices to income.

The actual price of water and wastewater at a consumption rate of $20 \mathrm{LCD}$ for each service is lower than the "affordability" benchmark of UNDP (2006) - 3\% of income for all of our 308 cities, but that comparison is not terribly realistic. First, GDP per capita overstates the income of an average individual and definitely fails to consider income distribution. If it is assumed there is an income equal to $25 \%$ of per capita GDP, for example, then the price of 20 LCD services exceeds $3 \%$ of that income in five countries, with the least affordable urban water in Ouagadougu, Kathmandu, and Kampala. Second, 20 LCD is not very much. The cost of consuming 135 LCD in services (per Chenoweth, 2008 ) would exceed $3 \%$ of income - again based on $25 \%$ of average GDP per capita - in 80 of 308 countries. It is for the reader decide whether tariffs are too high at those income and consumption levels.

\section{Conclusion}

This analysis of water tariff data from around the world reveals that water prices are relatively low and that low prices are correlated with higher water consumption and greater risk of shortages. Higher prices would not only reduce water consumption and the risk of shortage, they would also provide funds to operate, repair and expand water and wastewater services to people now forced to drink dirtier, more expensive and less convenient water.

\section{Acknowledgements}

The authors thank Damian Bickett, Paul Ferraro, Merton D. Finkler, Christopher Goemans, Heather Lang, Anke Leroux, Ankit Patel, Reagan Waskom, and two referees for helpful comments.

\section{References}

Arbués, F., García-Valiñas, M. A., \& Martínez-Espiñeira, R. (2003). Estimation of residential water demand: A state-of-the-art review. Journal of Socio-Economics, 32, 81-102. doi:10.1016/S1053-5357(03)00005-2.

Ariely, D. (2008). Predictably irrational. New York: Harper Collins.

Biswas, A. K. (2010). Water for a thirsty urban world. Brown Journal of World Affairs, 17, 147-162. Retrieved from http://www.bjwa.org/.

Chenoweth, J. (2008). Minimum water requirement for social and economic development. Desalination, 229, 245-256. doi:10.1016/j.desal.2007.09.011.

Dalhuisen, J. M., Florax, R. J. G. M., Groot, H. K. F., \& Nijkamp, P. (2003). Price and income elasticities of residential water demand: A meta-analysis. Land Economics, 79, 292-308. doi:10.3368/le.79.2.292.

The Economist (2011, July 14). Revolution spinning in the wind.

GWI (2011a). 2011 GWI OECD global water tariff survey. Global Water Intelligence, 12(9).

GWI (2011b). Global water market 2011. Oxford: Global Water Intelligence.

GWI (2011c). Global water risk index. Oxford: Global Water Intelligence.

Hammond, A., Kramer, W. J., Tran, J., Katz, R., \& Walker, C. (2007). The next 4 billion: Market size and business strategy at the base of the pyramid. Washington, DC: World Resources Institute and International Finance Corporation.

Hanemann, W. M. (2005). The economic conception of water. In P. P. Rogers, M. R. Llamas, \& L. Martinez Cortina (Eds.), Water crisis: Myth or reality? (pp. 61-92). Oxford: Taylor \& Francis. 
Howard, G., \& Bartram, J. (2003). Domestic water quantity, service, level and health. Geneva: World Health Organization.

IPCC (2007). Fourth assessment report: Climate change 2007. Geneva: Inter-governmental Panel on Climate Change.

ITU (2011). Mobile cellular subscriptions per 100 inhabitants, 2000-2010, International Telecommunications Union. Retrieved from http://www.itu.int/ict/statistics.

Jenerette, G. D., \& Larsen, L. (2006). A global perspective on changing sustainable urban water supplies. Global and Planetary Change, 50(3-4), 202-211. doi:10.1016/j.gloplacha.2006.01.004.

Kaufmann, D., Kraay, A., \& Mastruzzi, M. (2010). The worldwide governance indicators: Methodology and analytical issues (World Bank Policy Research Working Paper No. 5430). Retrieved from http://econ.worldbank.org.

Keener, S., Luengo, M., \& Banerjee, S. (2010). Provision of water to the poor in Africa: Experience with water standposts and the informal water sector (World Bank Policy Research Working Paper No. 5387). Retrieved from http://econ.worldbank.org.

Kjellén, M., \& McGranahan, G. (2006). Informal water vendors and the urban poor (Human Settlements Working Paper Series, Water, No. 3). Retrieved from http://pubs.iied.org/ 10529IIED.html.

Martinez-Espiñeira, R., García-Valiñas, M. A., \& González-Gómez, F. (2009). Does private management of water supply services really increase prices? An empirical analysis. Urban Studies, 46(4), 923-945. doi:10.1177/0042098009102135.

North, D. C., Wallis, J. J., \& Weingast, B. R. (2009). A conceptual framework for interpreting recorded human history. Cambridge: Cambridge University Press.

Ruester, S., \& Zschille, M. (2010). The impact of governance structure on firm performance: An application to the German water distribution sector. Utilities Policy, 18(3), 154-162. doi:10.1016/j.jup.2010.03.003.

Rygaard, M., Binning, P. J., \& Albrechtsen, H. -J. (2011). Increasing urban water self-sufficiency: New era, new challenges. Journal of Environmental Management, 92, 185-194. doi:10.1016/j.jenvman.2010.09.009.

Segerfeldt, F. (2005). Water for sale: How business and the market can resolve the world's water crisis. Washington, DC: Cato Institute.

Taylor, C. (2010, January 25). Water charges "to raise EUR 1 billion". Irish Times.

Thorsten, R. E., Eskaf, S., \& Hughes, J. (2009). Cost plus: Estimating real determinants of water and sewer bills. Public Works Management and Policy, 13(3), 224-238. doi:10.1177/1087724X08324302.

UNDP (2006). Human development report 2006. Beyond scarcity: Power, poverty and the global water crisis. New York: United Nations Development Programme.

UNDP (2011). Human development report 2011. Sustainability and equity: A better future for all. New York: United Nations Development Programme.

Whittington, D., Hanemann, W. M., Sadoff, C., \& Jeuland, M. (2009). The challenge of improving water and sanitation services in less developed countries. Foundations and Trends in Microeconomics, 4(6-7), 469-609. doi:10.1561/0700000030.

WHO/UNICEF (2011). Joint Monitoring Programme for Water Supply and Sanitation. Retrieved from http://www.wssinfo.org/data-estimates.

Zetland, D. (2011). The end of abundance: Economic solutions to water scarcity. Mission Viejo: Aguanomics Press. 


\section{Appendix 1: Regressions (data available upon request)}

Regression 1: LCD on watertariff, gdp (robust standard errors)

Robust linear regression

$\begin{array}{ll}\text { Number of obs }= & 61 \text { cities } \\ \mathrm{F}(2,58)= & 7.96 \\ \text { Prob }>\mathrm{F}= & 0.001 \\ R-\text { squared }= & 0.248 \\ \text { Root MSE }= & 101.75\end{array}$

\begin{tabular}{lrrrrrr}
\hline LCD & Coeff. & Std. err. & \multicolumn{1}{c}{$t$} & $P>t$ & \multicolumn{1}{c}{ [95\% conf. interval] } \\
\hline watertariff & -79.556 & 26.378 & -3.02 & $\mathbf{0 . 0 0 4}$ & -132.358 & -26.755 \\
gdp & 0.006 & 0.001 & 3.98 & $\mathbf{0 . 0 0 0}$ & 0.003 & 0.009 \\
constant & 181.704 & 23.878 & 7.61 & $\mathbf{0 . 0 0 0}$ & 133.908 & 229.501 \\
\hline
\end{tabular}

Data source: GWI (2011a).

Note: We dropped Tblisi and Belfast because their very high LCD (1800 and 900, respectively) increased estimated coefficients by a factor of three.

Regression 2: watertariff on pop, supply, demand, risk, ro (robust standard errors)

$\begin{array}{lll}\text { Robust linear regression } & \text { Number of obs. }= & 189 \text { cities } \\ & \mathrm{F}(4,184)= & 4.89 \\ & \text { Prob }>\mathrm{F}= & 0.001 \\ R-\text { squared }= & 0.064 \\ \text { Root MSE }= & 0.972\end{array}$

\begin{tabular}{lllrlll}
\hline watertariff & Coeff. & Std. err. & $t$ & $P>t$ & \multicolumn{1}{c}{ [95\% conf. interval] } \\
\hline pop & $-4.45 \mathrm{e}-08$ & $2.22 \mathrm{e}-08$ & -2.00 & $\mathbf{0 . 0 4 7}$ & $-8.82 \mathrm{e}-08$ & $-6.69 \mathrm{e}-10$ \\
supply & -0.000 & $6.92 \mathrm{e}-06$ & -2.74 & $\mathbf{0 . 0 0 7}$ & -0.000 & $-5.32 \mathrm{e}-06$ \\
demand & 0.001 & 0.000 & 1.65 & $\mathbf{0 . 1 0 1}$ & -0.000 & 0.001 \\
risk & -0.413 & 0.179 & -2.30 & $\mathbf{0 . 0 2 3}$ & -0.767 & -0.059 \\
constant & 1.433 & 0.151 & 9.48 & $\mathbf{0 . 0 0 0}$ & 1.135 & 1.732 \\
\hline
\end{tabular}

Data sources: GWI (2011a,2011c).

Note: The proponderance of 0 and 1 values for risk may lead to biased OLS estimates. A comparison of OLS and ordered probit regressions with risk as the dependent variable returns statistically significant coefficients in the same direction as Regression 2.

Regression 3: watertariff on tap_cover, gov, gdp, ro (robust standard errors)

Robust linear regression

$\begin{array}{ll}\text { Number of obs. }= & 102 \text { countries } \\ \mathrm{F}(3,98)= & 26.62 \\ \text { Prob }>\mathrm{F}= & 0.000 \\ R-\text { squared }= & 0.524 \\ \text { Root MSE }= & 0.776\end{array}$




\begin{tabular}{lrlrrrr}
\hline watertariff & Coeff. & Std. err. & $t$ & $P>t$ & [95\% conf. interval] \\
\hline tap_cover & -0.004 & 0.002 & -1.72 & $\mathbf{0 . 0 8 8}$ & -0.008 & 0.001 \\
gov & 0.025 & 0.005 & 4.58 & $\mathbf{0 . 0 0 0}$ & 0.014 & 0.036 \\
gdp & 0.000 & $5.81 \mathrm{e}-06$ & 2.04 & $\mathbf{0 . 0 4 4}$ & $3.08 \mathrm{e}-07$ & 0.000 \\
constant & -0.214 & 0.221 & -0.97 & 0.334 & -0.652 & 0.224 \\
\hline
\end{tabular}

Data sources: Kaufmann et al. (2010), GWI (2011a) and WHO/UNICEF (2011).

Regression 4: tap_cover on watertariff, gov, gdp, ro (robust standard errors)

Robust linear regression

$\begin{array}{ll}\text { Number of obs. }= & 102 \text { countries } \\ \mathrm{F}(3,98)= & 19.93 \\ \text { Prob }>\mathrm{F}= & 0.000 \\ R-\text { squared }= & 0.338 \\ \text { Root } \mathrm{MSE}= & 21.357\end{array}$

\begin{tabular}{lrrrrrr}
\hline tap_cover & Coeff. & Std. err. & \multicolumn{1}{c}{$t$} & $P>t$ & [95\% conf. interval] \\
\hline watertariff & -2.752 & 1.678 & -1.64 & $\mathbf{0 . 1 0 4}$ & -6.081 & 0.577 \\
gov & 0.548 & 0.137 & 4.00 & $\mathbf{0 . 0 0 0}$ & 0.276 & 0.820 \\
gdp & 0.000 & 0.000 & 1.70 & $\mathbf{0 . 0 9 1}$ & -0.000 & 0.000 \\
constant & 50.521 & 7.159 & 7.06 & $\mathbf{0 . 0 0 0}$ & 36.315 & 64.727 \\
\hline
\end{tabular}

Data sources: Kaufmann et al. (2010), GWI (2011a) and WHO/UNICEF (2011).

Regression 5: tap_cover on gov, watertariff, risk, ro (robust standard errors)

$\begin{array}{lll}\text { Robust linear regression } & \text { Number of obs. }=75 \text { countries } \\ & \mathrm{F}(3,71)= & 19.29 \\ & \text { Prob }>\mathrm{F}= & 0.000 \\ & R \text {-squared }= & 0.495 \\ & \text { Root MSE }= & 18.824\end{array}$

\begin{tabular}{lrrrrrr}
\hline tap_cover & Coeff. & Std. err. & \multicolumn{1}{c}{$t$} & $P>t$ & [95\% conf. interval] \\
\hline gov & 0.599 & 0.139 & 4.31 & $\mathbf{0 . 0 0 0}$ & 0.322 & 0.877 \\
watertariff & -1.614 & 3.088 & -0.52 & 0.603 & -7.771 & 4.544 \\
risk & 24.472 & 5.109 & 4.79 & $\mathbf{0 . 0 0 0}$ & 14.284 & 34.660 \\
constant & 37.116 & 8.271 & 4.49 & $\mathbf{0 . 0 0 0}$ & 20.624 & 53.608 \\
\hline
\end{tabular}

Data sources: Kaufmann et al. (2010), GWI (2011a, 2011c) and WHO/UNICEF (2011).

Regression 6: tap_cover on watertariff, supply, demand, risk, gov, gdp, ro (robust standard errors)

Robust linear regression

$\begin{array}{ll}\text { Number of obs. }= & 75 \text { countries } \\ \mathrm{F}(6,68)= & 52.07 \\ \text { Prob }>\mathrm{F}= & 0.000 \\ R-\text { squared }= & 0.519 \\ \text { Root } \mathrm{MSE}= & 18.77\end{array}$




\begin{tabular}{lrrrrrr}
\hline tap_cover & Coeff. & Std. err. & \multicolumn{1}{l}{$t$} & $P>t$ & [95\% conf. interval] \\
\hline watertariff & -2.524 & 2.999 & -0.84 & 0.403 & -8.508 & 3.459 \\
supply & -0.001 & 0.000 & -3.56 & $\mathbf{0 . 0 0 1}$ & -0.009 & -0.000 \\
demand & 0.013 & 0.009 & 1.38 & 0.172 & -0.006 & 0.031 \\
risk & 20.747 & 5.280 & 3.93 & $\mathbf{0 . 0 0 0}$ & 10.212 & 31.282 \\
gov & 0.506 & 0.203 & 2.50 & $\mathbf{0 . 0 1 5}$ & 0.102 & 0.910 \\
gdp & 0.000 & 0.000 & 0.64 & 0.526 & -0.000 & 0.001 \\
constant & 41.245 & 9.799 & 4.21 & $\mathbf{0 . 0 0 0}$ & 21.692 & 60.798 \\
\hline
\end{tabular}

Data sources: Kaufmann et al. (2010), GWI (2011a, 2011c) and WHO/UNICEF (2011).

Regression 7: watertariff on tap_cover, supply, demand, risk, gov, gdp, ro (robust standard errors)

Robust linear regression

$\begin{array}{ll}\text { Number of obs. }= & 75 \text { countries } \\ \mathrm{F}(6,68)= & 13.78 \\ \text { Prob }>\mathrm{F}= & 0.000 \\ R-\text { squared }= & 0.590 \\ \text { Root } \mathrm{MSE}= & 0.639\end{array}$

\begin{tabular}{lclrlrl}
\hline watertariff & Coeff. & Std. err. & $t$ & $P>t$ & [95\% conf. interval] \\
\hline tap_cover & -0.003 & 0.003 & -0.84 & 0.406 & -0.010 & 0.004 \\
supply & $-4.76 \mathrm{e}-06$ & $3.42 \mathrm{e}-06$ & -1.39 & 0.169 & -0.000 & $2.06 \mathrm{e}-06$ \\
demand & 0.000 & 0.000 & 0.80 & 0.426 & -0.000 & 0.001 \\
risk & -0.129 & 0.239 & -0.54 & 0.591 & -0.605 & 0.347 \\
gov & 0.015 & 0.006 & 2.65 & $\mathbf{0 . 0 1 0}$ & 0.004 & 0.026 \\
gdp & 0.000 & $9.11 \mathrm{e}-06$ & 2.41 & $\mathbf{0 . 0 1 9}$ & $3.79 \mathrm{e}-06$ & 0.000 \\
constant & 0.037 & 0.246 & 0.15 & 0.882 & -0.455 & 0.528 \\
\hline
\end{tabular}

Data sources: Kaufmann et al. (2010), GWI (2011a, 2011c) and WHO/UNICEF (2011). 